\title{
Tailored one-pot production of furan-based fuels from fructose in an ionic liquid biphasic solvent system
}

\author{
Changzhi Li a, Haile Cai a, Bo Zhang a, Weizhen Li a, Guangxian Pei a,b, Tao Dai a,b , Aiqin Wang a,c, \\ Tao Zhang a,c,* \\ a State Key Laboratory of Catalysis, Dalian Institute of Chemical Physics, Chinese Academy of Sciences, Dalian 116023, China \\ b University of Chinese Academy of Sciences, Beijing 100049, China \\ c Collaborative Innovation Center of Chemistry for Energy Materials (iChEM), Dalian 116023, Liaoning, China
}

\section{A R T I C L E I N F O}

Article history:

Received 29 March 2015

Accepted 3 June 2015

Published 20 September 2015

\section{Keywords:}

Biomass

Ionic liquids

2,5-Dimethylfuran

2,5-Dimethyltetrahydrofuran

5-Hydroxylmethylfufural

Fructose

Biofuel

\begin{abstract}
A B S T R A C T
The one-pot catalytic transformation of biomass to useful products is desirable for saving cost and time. The integration of the various reaction steps need to address the presence of incompatible reaction conditions and numerous side reactions. We report a novel process for the one-pot production of furan-based fuels, 2,5-dimethylfuran (DMF) and 2,5-dihmethyltetrahydrofuran (DMTF), from fructose by optimizing the synergic effect of an ionic liquid promoted $\mathrm{Ru} / \mathrm{C}$ catalyst and the solvent effect. The dehydration of fructose and subsequent in situ hydrodeoxygenation of HMF to DMF and DMTF on Ru/C were enhanced by the use of an ionic liquid and a biphasic [BMIm]Cl/THF solvent. Elemental analysis, X-ray Photoelectron Spectroscopy, Raman spectroscopy and $\mathrm{H}_{2}$-temperature programmed reduction-mass spectroscopy characterization showed that the ionic liquid modified the electronic density of the Ru species to favor HMF in situ hydrodeoxygenation. Moreover, THF served as a reaction-extraction solvent that extracted DMF and DMTF from the reaction layer to avoid further side reactions. A rational design that gave enhancement of the catalytic performance and product protection provides a promising strategy for the one-pot conversion of biomass to desired fuels.
\end{abstract}

(C) 2015, Dalian Institute of Chemical Physics, Chinese Academy of Sciences. Published by Elsevier B.V. All rights reserved.

\section{Introduction}

With the increasing depletion of fossil fuels and the concerns over their environmental impact and greenhouse gas effect, the development of renewable energy resources becomes more urgent. Biomass is the only renewable organic carbon source in nature, which endows it with unique advantages in producing fuels and industrially important chemicals [1-4]. Among the various valuable compounds derived from biomass, 2,5-dimethylfuran (DMF) and 2,5-dimethyltetrahydrofuran (DMTF) have received particularly attention because they are good biofuel candidates and important intermediates in the chemical industry. As a fuel replacement, DMF has an ideal boiling point $\left(92-94{ }^{\circ} \mathrm{C}\right)$, high energy density (30 $\mathrm{kJ} / \mathrm{cm}^{-3}$ ), and high research octane number (RON = 119) [5]. It is also an intermediate for making $p$-xylene, one of the highest volume bulk chemical presently derived from petroleum $[6,7]$. DMTF is the extensively reduced product of DMF. It has a high-

\footnotetext{
* Corresponding author. Tel: +86-411-84379015; Fax: +86-411-84691570; E-mail: taozhang@dicp.ac.cn This work was supported by the National Natural Science Foundation of China $(21473187,21403213)$ and China Postdoctoral Science Foundation (2015M571341).

DOI: 10.1016/S1872-2067(15)60927-5 | http://www.sciencedirect.com/science/journal/18722067 | Chin. J. Catal., Vol. 36, No. 9, September 2015
} 
er energy content than DMF and has better stability during storage because of its saturated furan ring structure [5]. DMTF can also serve as a substitute for tetrahydrofuran (THF) in the chemical industry [8].

In principle, DMF and DMTF can be generated from carbohydrates via hydrolysis, dehydration and subsequently selective hydrogenation reactions (Scheme 1). Currently, most studies are focused on the hydrodeoxygenation of 5-hydroxymethylfurfural (HMF) to produce DMF and DMTF [9, 10]. However, HMF is a versatile compound with many important applications, thus using cheap and abundant biomass derived carbohydrate instead of the more expensive HMF as the substrate for the production of these two products is more cost effective and preferable.

As an example of starting from carbohydrates, Dumesic's group [5] pioneered a biphasic two-step process for the conversion of fructose into DMF. In this study, fructose was first dehydrated to HMF in an aqueous/organic system over an acid catalyst. The purified HMF was subsequently converted to DMF via liquid- or vapour phase hydrodeoxygenation reaction over $\mathrm{CuRu} / \mathrm{C}$. The highest overall yield of $50 \%$ was obtained directly from carbohydrates in a relatively complicated reaction system with the use of a number of additives. Subsequently, Chidambaram et al. [11] and Binder et al. [12] used glucose and corn stover as substrates for the production of DMF via two- or multi-step approaches. Both studies obtained fairly good yields of the intermediate HMF. Unfortunately, in the hydrodeoxygena-

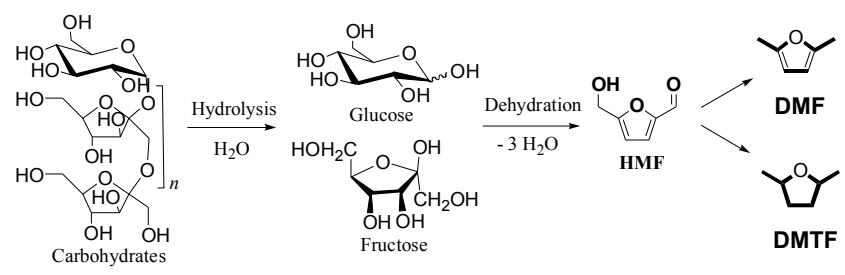

Scheme 1. Reaction route for the conversion of biomass to furan-based fuels DMF and DMTF.

tion step, due to the influence of unfavorable impurities, the overall yields of DMF were only $15 \%$ and $9 \%$, respectively, in the above two cases.

One-pot catalysis is a powerful strategy in green chemistry. Combining multi-step transformations in one-pot cascade catalysis would provide advantages over conventional processes with stepwise reactions, mainly by reducing the time used and yield losses during the isolation and purification of the reaction products. In the catalytic transformation of carbohydrates to DMF and DMTF, due to the incompatible reaction conditions of each step and the numerous side reactions, it is a challenge to perform a one-pot conversion process [13]. Therefore, in the above three examples, the isolation of the intermediate HMF was a prerequisite for the subsequent hydrodeoxygenation reaction.

Sen et al. [14] recently provided an elegant example of the one-pot conversion of carbohydrates to DMTF. In their experi-
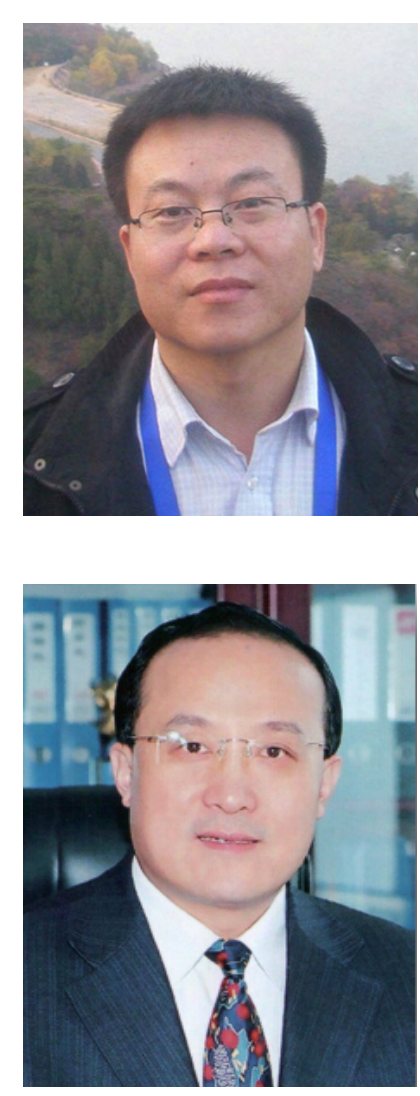

Changzhi Li (Dalian Institute of Chemical Physics, Chinese Academy of Science) received Min Enze Energy and Chemical Engineering Award in 2013, which was jointly presented by Chinese Academy of Engineering and Sinopec Group, for his contribution in the area of "ionic liquids mediated biomass conversion". Dr Changzhi Li received his Ph.D. degree under the supervision of Prof. Zongbao (kent) Zhao, in Organic Chemistry from Dalian Institute of Chemical Physics, Chinese Academy of Sciences, in 2009; then he joined Prof. Tao Zhang's group where he was promoted to an associated professor in 2012. He has published more than 20 peer-reviewed papers with over 600 citations. In 2014, he won the First Prize for Dalian Science and Technology Innovation Award. His current research focuses on the catalytic depolymerization of lignin and the production of bulk and fine chemicals from renewable sources.

Tao Zhang (Dalian Institute of Chemical Physics, Chinese Academy of Science) received the Catalysis Award for Young Scientists in 2008, which was presented by The Catalysis Society of China. Professor Tao Zhang received his Ph.D. degree from Dalian Institute of Chemical Physics (DICP), Chinese Academy of Sciences, in 1989, and he joined the same institute and was promoted to full professor in 1995. He did postdoctoral research with Prof. Frank Berry at Birmingham University in 1990. Prof. Zhang was an invited professor at Univesity of Poitiers (France) in 2006-2007, and he has been a guest professor at University of Namur (Belgium) since 2011. He is currently the director of DICP (since 2007). Prof. Zhang has also received several research awards, including the Distinguished Award of Chinese Academy of Sciences (2010), Zhou Guangzhao Foundation Award for Applied Science (2009), National Award of Technology Invention $(2008,2006,2005)$. He was selected as an academician of the Chinese Academy of Sciences. In the past decades, Prof. Zhang has successfully designed a great number of nano and subnano metallic catalysts for applications in energy conversion and environmental control. His research interests include (1) Design and synthesis of nano- and subnano catalytic materials; (2) utilization of biomass for production of chemicals. 
ments, a homogeneous catalyst system composed of a soluble $\mathrm{Rh}$ salt was the catalyst, and $\mathrm{HI}$ and chlorobenzene as additives under a hydrogen atmosphere in water was applied. Hexose from a wide range of biomass-derived carbohydrates were converted into DMTF in good yields. Rauchfuss's group [13] also developed a formic acid participant process for the synthesis of DMF from fructose whereby three steps occurred in the one-pot, namely, dehydration of fructose to HMF, hydrogenation HMF to bis(hydroxymethyl)-furan (BHMF), and deoxygenation of BHMF to DMF. While promising, too much FA used (over 10 times molar amount than fructose) in the process is an issue that needs to be addressed.

Ionic liquids (ILs) are currently under intensive investigation as alternative solvents for biomass conversion because they possess tunable properties and readily dissolve biomass resources [15-18]. In our previous study, we developed the dehydration of carbohydrates for the production of HMF in ILs [19] and the one-pot conversion of carbohydrates to furan-based diols in a IL/water binary solvent mixture [20]. Here, the direct production of DMF and DMTF from fructose via one-pot tandem reaction in a biphasic IL/organic solvent system over $\mathrm{Ru} / \mathrm{C}$ was rationally designed. This ensured the coupling of the relevant reactions and designed the selectivity to DMF and DMTF. The solvent effect and the role of IL in the transformation process were clearly explained.

\section{Experimental}

\subsection{Materials}

Fructose (99\%) was purchased from Acros Organics. All the other chemicals were obtained from local supplier and were used as received without further purification. The $\mathrm{Ru} / \mathrm{C}$ catalyst was prepared by incipient wet impregnation followed by reduction in $\mathrm{H}_{2}$ at $300{ }^{\circ} \mathrm{C}$ for $1 \mathrm{~h}$. 1-Butyl-3-methylimidazolium chloride ([BMIm]Cl) was prepared according to our previous study [20].

\subsection{Conversion of fructose for the production of DMF and DHMTF}

A typical process for the catalytic conversion of fructose is as follows. $0.36 \mathrm{~g}$ fructose and $1.0 \mathrm{~g}$ [BMIm]Cl were charged into an open autoclave and heated to $130{ }^{\circ} \mathrm{C}$ for $30 \mathrm{~min}$ to afford HMF. About $20 \mathrm{mg}$ sample was withdrawn, weighed, quenched with cold water, and subjected to HPLC analysis to determine the fructose conversion and HMF yield. $25 \mathrm{~mL}$ organic solvent and $0.1 \mathrm{~g}$ metal catalyst were added to the residue reaction mixture. After the solution was mixed uniformly, the hydrodeoxygenation reaction was carried out with an initial $\mathrm{H}_{2}$ pressure of $5 \mathrm{MPa}$ (measured at room temperature) at $220{ }^{\circ} \mathrm{C}$ for a set time. After the one-pot transformation, the reaction solution was filtered and the clear filtrate was subject to GC-MS analysis using the external standard method.

The HPLC analysis of the products was conducted on a Agilent 1100 equipment with a Shodex SC-101 column using extra pure water as the mobile phase at a flow rate of $0.6 \mathrm{~mL} / \mathrm{min}$.
The pressure of the column was 2.8 $\mathrm{MPa}$ and the column temperature was $45{ }^{\circ} \mathrm{C}$. The yield of HMF was calculated by the equation: Yield $(\%)=($ molar number of $\mathrm{HMF}) \div($ molar number of fructose) $\times 100$. The conversion of HMF was calculated by the equation: Conversion $(\%)=(1-($ molar number of the left $\mathrm{HMF}) \div($ molar number of HMF from substrates $)) \times 100$. The selectivity of DMF or DMTF was calculated by the equation: Selectivity $(\%)=$ (molar number of the product $) \div($ molar number of converted HMF) $\times 100$. The total selectivity of furan-based fuels was calculated by the equation: Selectivity (\%) $=($ Selectivity of DMF $)+($ Selectivity of DMTF $)$. The total yield of furan-based diols was calculated by the equation: Total yield $(\%)=($ Yield of HMF $) \times($ Conversion of HMF $) \times($ Total selectivity of furan-based fuels) $\times 100$.

\subsection{Characterization}

Elemental analysis $(\mathrm{C}, \mathrm{H}, \mathrm{N})$ of the catalyst was done on a Vario MICRO elemental analyzer. Raman spectra were measured with a Raman spectrometer (Renishaw in Via Raman Microscope) equipped with a He-Ne (514 nm) laser. A laser power of $0.1 \mathrm{~mW}$ was used to avoid overheating of the sample. $\mathrm{H}_{2}$ temperature programmed reduction (TPR) was performed using a Micromeritics Autochem 2910 (USA) equipment with 5 vol\% of $\mathrm{H}_{2} / \mathrm{N}_{2}(50 \mathrm{~mL} / \mathrm{min})$ at a heating rate of $10{ }^{\circ} \mathrm{C} / \mathrm{min}$ from 50 to $800^{\circ} \mathrm{C}$. The sample (50 mg) was pretreated with He flow $\left(30 \mathrm{~mL} / \mathrm{min}\right.$ ) at $120^{\circ} \mathrm{C}$ for $30 \mathrm{~min}$. The outlet gas was analyzed by a TCD and mass spectroscopy (MS). X-ray photoelectron spectroscopy (XPS, JEOL JPC-9010MC) for the Ru 3p $3 / 2$ peak was obtained using $\mathrm{Al} K_{\alpha}$ radiation $(1486.6 \mathrm{eV})$ at $100 \mathrm{~W}$ and a pass energy of $30 \mathrm{eV}$. Samples were fixed on a double-stick carbon tape. The binding energies were calibrated using sputtered $\mathrm{Au}\left(4 f_{7 / 2}\right.$ peak at $\left.83.8 \mathrm{eV}\right)$.

\section{Results and discussion}

\subsection{Fructose dehydration in ILs}

A typical reaction profile in this work is a one-pot two-step procedure, i.e., dehydration of fructose to produce HMF, coupled with in situ hydrodeoxygenation of HMF to afford the target products DMF and DMTF. In the first step, the dehydration reaction in [BMIm] Cl without the addition of catalyst at $130{ }^{\circ} \mathrm{C}$ within 30 min afforded HMF in $(78 \pm 3) \%$ yield. Further prolonging the reaction time did not enhance the HMF yield, while the color of the mixture turned dark, suggesting the formation of black humins. As the fructose dehydration reaction in aqueous solution is inert when no catalyst is used [21], [BMIm]Cl plays the role not only of the appropriate solvent but also as an advantageous promoter for HMF production. In the following one-pot cascade conversion of carbohydrates experiments, the fructose dehydration reaction were all conducted at $130{ }^{\circ} \mathrm{C}$ for $30 \mathrm{~min}$ and then the next in situ hydrodeoxygenation step was performed.

\subsection{In situ hydrodeoxygenation: solvent effect}


In comparison to water and common organic solvents, most ILs including [BMIm]Cl have an undesirable high viscosity [22]. This property is especially unfavorable for mass transfer in the gas reactions. In the HMF hydrodeoxygenation step, to alleviate the negative effect of the high viscosity, after the dehydration reaction, another solvent with a lower viscosity was added into the reaction mixture for the hydrodeoxygenation reaction. As the IL/water mixture was proved to be not a choice for the hydrodeoxygenation of HMF [20], organic solvents with different properties were screened to find a proper system for the production of DMF and DMTF.

For the in situ hydrodeoxygenation step, it was found, as shown in Fig. 1, that HMF was completely consumed in all the solvent mixtures within $5 \mathrm{~h}$ over $\mathrm{Ru} / \mathrm{C}$, while the selectivities of the products were totally different. When dipolar organic solvents were applied in the hydrodeoxygenation step, they are miscible with [BMIm]Cl in all ratios. In this case, regardless whether they are protic (such as i-propanol and $n$-butanol) or aprotic (such as $\mathrm{CH}_{3} \mathrm{CN}$ ), rather poor yields between $11 \%-15 \%$ were obtained. The GC-MS analysis implied that severe side reactions occurred because many byproducts such as furan ring-opening products, carbonyl group and $\mathrm{C}=\mathrm{C}$ bond hydrogenation products as well as demethylation products and some unknown products were detected.

It is interesting to note that THF, a weak dipolar aprotic solvent that is immiscible with [BMIm]Cl, afforded a much higher selectivity of furan-based fuels with a total yield of $68 \%$ (DMF: $49 \%$ and DMTF: 19\%, based on HMF). In comparison to the above strong dipolar solvents, THF in IL greatly enhanced the selectivity of furan-based fuels. Although a clear explanation for the enhancement remains speculative, we would like to offer some discussion. First, in the biphasic solvent system of THF/IL, HMF was highly soluble in IL and $\mathrm{Ru} / \mathrm{C}$ was also present in the IL phase. This "solvent cage effect" [23] increased the collision probability and thus made the catalyst more accessible to HMF. Furthermore, as soon as DMF and DMTF were

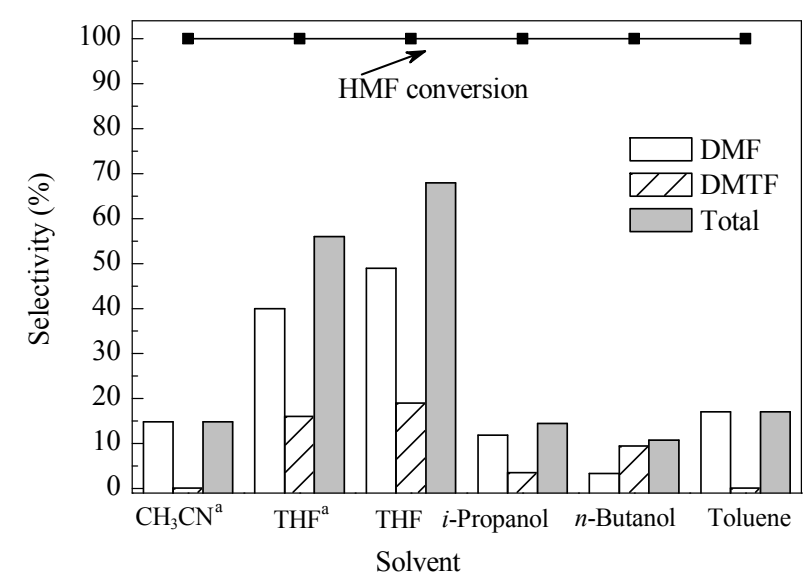

Fig. 1. Direct conversion of fructose into furan-based fuels in a binary mixture of [BMIm]Cl/organic solvent. Reaction conditions: $0.36 \mathrm{~g}$ fructose was dehydrated in $1.0 \mathrm{~g}$ [BMIm] Cl at $130{ }^{\circ} \mathrm{C}$ for $30 \mathrm{~min}$, then $25 \mathrm{~mL}$ organic solvent and $0.1 \mathrm{~g} \mathrm{Ru} / \mathrm{C}(5 \mathrm{wt} \%)$ were added into the mixture for the hydrogenolysis reaction under $5 \mathrm{MPa} \mathrm{H}_{2}$ at $220^{\circ} \mathrm{C}$ for $5 \mathrm{~h}$. a. Neat $\mathrm{HMF}$ was used as the substrate for the hydrodeoxygenation reaction. formed, the low solubility of these two products in the dipolar IL facilitated the shift of the products to the THF layer. Accordingly, ring-opening and other side reactions were avoided. In contrast, this "solvent cage effect" and the so called "reaction-extraction effect" did not exist in the binary solvent system comprising the IL and a dipolar organic solvent, such as $\mathrm{CH}_{3} \mathrm{CN}$, $i$-propanol and $n$-butanol, because these organic solvents are miscible with [BMIm]Cl. Besides, different solvents affect the equilibrium constant of a reaction by different stabilization of the reactant or product through H-bonding, dipole-dipole interactions, van der Waals interactions, etc. [23].

It should be pointed out that in THF/IL, the hydrodeoxygenation of neat HMF afforded a lower performance (DMF and DMTF yields of $40 \%$ and $16 \%$, with the total yield of $56 \%$ ) than that acquired directly from fructose (Fig. 1, the two comparative reactions in the THF/IL system). Noting that the dehydration reaction of fructose generated $23 \%$ byproducts, the comparative experiments with fructose and HMF indicated that the impurities formed in the dehydration reaction did not have an undesirable influence on the subsequent hydrodeoxygenation reaction. Therefore, the removal of the impurities was not a prerequisite in our experiment. This is an advantage over the stepwise technology because it avoided the isolation and purification of HMF without compromising the yield of furan-based fuels.

For the hydrotreating of biomass, the hydrogen pressure and the reaction temperature are two crucial factors affecting the conversion. In the THF/IL system, optimization of the reaction conditions showed that the catalytic performance was only slightly enhanced with the increasing of hydrogen pressure (Fig. 2(a)). In contrast, it was more sensitive to the reaction temperature (Fig. 2(b)), suggesting that hydrodeoxygenation is a thermodynamic controlling reaction in THF/IL over the $\mathrm{Ru} / \mathrm{C}$ catalyst. These results were quite different from our previous study where in the hydrogenation of HMF to furan-based diols, the hydrogen pressure was the key factor that controlled the overall rate [20].

\subsection{Effect of water on the in situ hydrodeoxygenation of HMF}

It is known that in the fructose dehydration reaction, three water molecules are released for the formation of one $\mathrm{HMF}$ molecule. In the IL reaction system, once water is generated, it is hard to separate it from the IL due to the interactions between the IL and water $[24,25]$. To identify the influence of water in our system, we attempted the neat HMF hydrodeoxygenation reaction in THF/IL with different amounts of water. It is interesting to find in Table 1 that in a certain range, the yield of furan-based fuels increased with increasing water amount. For instance, on increasing the water amount from zero to 6 mmol (one molar equivalent of IL), the total yield of the target products increased from 56\% (DMF 40\%, DMTF 16\%) to $67 \%$ (DMF 47\%, DMTF 20\%). These results oppose the common sense that water would induce side reactions which then decrease the product selectivity [26]. The following two reasons are believed to cause this exceptional positive effect: (1) improvement of the mass transfer, since low viscosity water is 

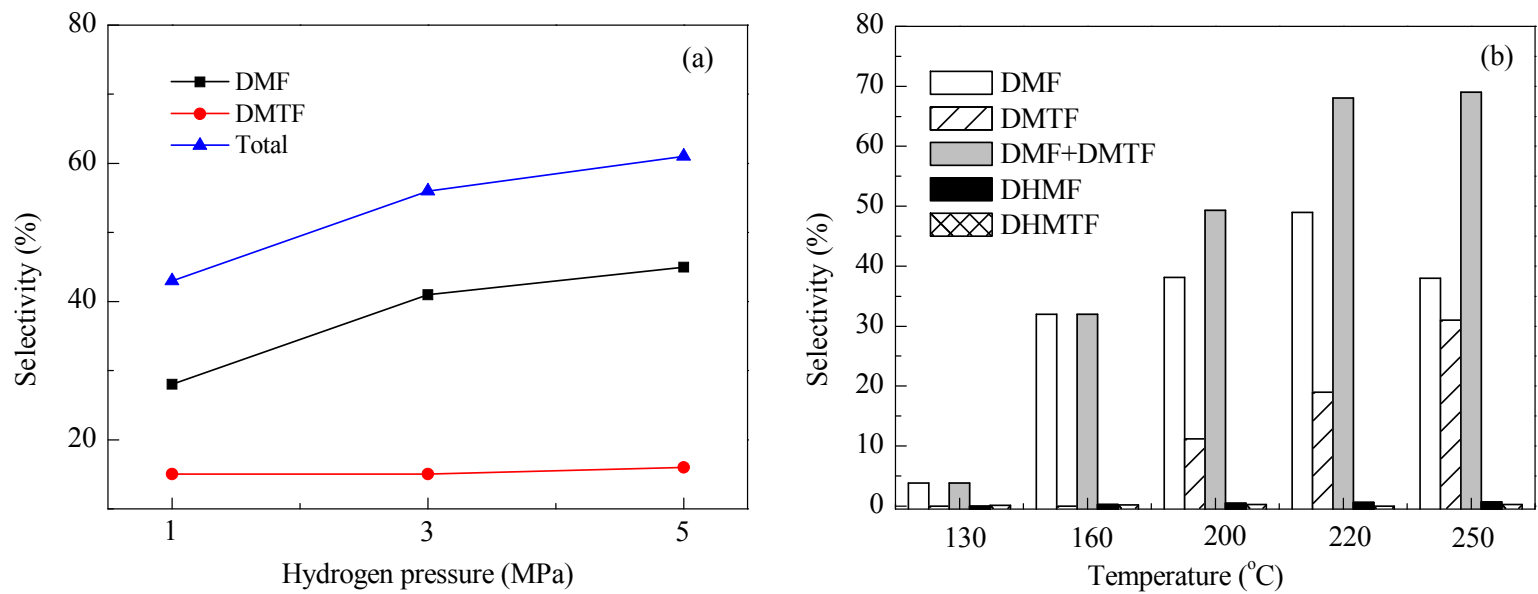

Fig. 2. Effects of hydrogen pressure (a) and reaction temperature (b) on the hydrodeoxygenation performance. Reaction conditions: (a) Dehydration reaction was first conducted in $1.0 \mathrm{~g}$ [BMIm] Cl at $130{ }^{\circ} \mathrm{C}$ with $0.36 \mathrm{~g}$ fructose for $30 \mathrm{~min}$, then $25 \mathrm{~mL} \mathrm{THF}$ and $0.1 \mathrm{~g} 5 \% \mathrm{Ru} / \mathrm{C}$ were added into the mixture for the hydrodeoxygenation reaction under $\mathrm{H}_{2}$ atmosphere at $220^{\circ} \mathrm{C}$ for $10 \mathrm{~h}$; (b) The dehydration condition was the same; the hydrodeoxygenation reaction was carried out under $5 \mathrm{MPa} \mathrm{H}_{2}$ at different temperatures for $5 \mathrm{~h}$.

Table 1

Effect of water amount on the production of furan-based fuels a.

\begin{tabular}{|c|c|c|c|c|c|}
\hline \multirow{2}{*}{ Entry } & \multirow{2}{*}{$\begin{array}{l}\mathrm{H}_{2} \mathrm{O} \\
(\mathrm{g})\end{array}$} & \multirow{2}{*}{$\begin{array}{c}\text { HMF conv. } \\
(\%)\end{array}$} & \multicolumn{3}{|c|}{ Yield (\%) } \\
\hline & & & DMF & DMTF & Total \\
\hline 1 & 0 & $>99$ & 40 & 16 & 56 \\
\hline 2 & 0.036 & $>99$ & 48 & 18 & 66 \\
\hline 3 & 0.108 & $>99$ & 47 & 20 & 67 \\
\hline 4 & 0.500 & $>99$ & 33 & 18 & 51 \\
\hline 5 & 1.000 & $>99$ & 18 & 5 & 23 \\
\hline
\end{tabular}

a Reaction conditions: HMF $0.252 \mathrm{~g}$, THF $25 \mathrm{~mL}, 5 \% \mathrm{Ru} / \mathrm{C} 0.1 \mathrm{~g}$, [BMIm] Cl $1.0 \mathrm{~g}$. The hydrogenation reaction was carried out under 5 $\mathrm{MPa} \mathrm{H}_{2}$ at $220^{\circ} \mathrm{C}$ for $5 \mathrm{~h}$.

miscible with IL in any ratio, and (2) strong interactions such as hydrogen bonds between water and IL suppressed water related side reactions, e.g. rehydration, hydrolysis of HMF and intermediates $[24,25,27]$. It should be noted that the effect of the IL-water interaction became weaker when much water is present in the reaction system. This is the reason why the yield of furan-based fuels reached a peak with the presence of 6 mmol water, and then decreased when the water amount was higher (entry 3 versus entries 4 and 5, Table 1). Actually, we also tested the reaction in a ternary solvent system ([BMIm]Cl/THF $/ \mathrm{H}_{2} \mathrm{O}, v / v / v=1: 15: 10$ ) over $\mathrm{Ru} / \mathrm{C}$ at $220^{\circ} \mathrm{C}$. No DMF or DMTF was detected even on prolonging the reaction time to $10 \mathrm{~h}$. Instead, 2,5-dihydroxymethylfuran (DHMF) and 2,5-dihydroxymethyltetrahydrofuran (DHMTF) were the dominant products with the total yield of $88 \%$. This result is in accordance with our previous study [20] that HMF undergoes a hydrogenation reaction in a solvent system containing a large amount of water. Noting that the fructose concentration was far less than that of the IL, it can be concluded that the small amount of water formed in the fructose dehydration step did not cause a negative effect on the next hydrodeoxygenation reaction. In contrast, it is an advantage of the one-pot catalytic system over the stepwise technology since the water produced promoted the formation of DMF and DMTF.

\subsection{The role of the IL on the in situ hydrodeoxygenation reaction}

It is known that the IL plays an important role in the fructose dehydration reaction. To explore the function of the IL in the hydrodeoxygenation step, using HMF as the substrate, we compared the reaction with different amounts of IL under otherwise identical conditions.

As shown in Table 2 (entry 1), in the absence of the IL, although the fructose conversion was very high in the THF solvent, the products only comprised 2\% DMTF and a trace amount of DMF. Instead, DHMTF, 5-methyl tetrahydrofurfuryl alcohol (MTFA), tetrahydrofurfuryl alcohol (TFA), 1,2-pentanediol, 2-hexanol and pentanol were detected as the main products in the liquid phase. In addition, gas products of $\mathrm{CO}_{2}, \mathrm{CH}_{4}$ and $\mathrm{C}_{2} \mathrm{H}_{6}$, and some insoluble humins were formed. According to the MS data and Ref. [11], we proposed the byproduct formation pathways (Fig. 3): HMF was first saturated

Table 2

Effects of [BMIm] Cl amount on the production of furan-based fuels a.

\begin{tabular}{lccccc}
\hline \multirow{2}{*}{ Entry } & $\begin{array}{c}{[\mathrm{BMIm}] \mathrm{Cl}} \\
(\mathrm{mmol})\end{array}$ & $\begin{array}{c}\text { HMF conv. } \\
\text { (\%) }\end{array}$ & \multicolumn{3}{c}{ Yield (\%) } \\
\hline 1 & 0 & $>99$ & 0 & 2 & 2 \\
2 & 1.15 & $>99$ & 32 & 1 & 33 \\
3 & 2.87 & $>99$ & 41 & 12 & 53 \\
4 & 5.73 & $>99$ & 47 & 20 & 67 \\
5 & 11.46 & $>99$ & 30 & 14 & 44 \\
$6^{\mathrm{b}}$ & 0 & $>99$ & 66 & 1 & 67 \\
$7^{\mathrm{c}}$ & 5.73 & $>99$ & 0 & 2 & 2 \\
$8^{\mathrm{d}}$ & 5.73 & $>99$ & 40 & 19 & 59
\end{tabular}

a HMF 0.252 g, THF $25 \mathrm{~mL}, 5 \% \mathrm{Ru} / \mathrm{C} 0.100 \mathrm{~g}$ and $\mathrm{H}_{2} \mathrm{O} 0.108 \mathrm{~g}$. The hydrodeoxygenation reaction was conducted at $220^{\circ} \mathrm{C}$ under $5 \mathrm{MPa}_{2}$ for $5 \mathrm{~h}$.

${ }^{\mathrm{b}}$ Catalyst was $\mathrm{Ru} / \mathrm{C}-\mathrm{IL}$, other conditions were the same as entry 4 .

c [BMIm] $\mathrm{Cl}$ was replaced by $\mathrm{NaCl}$, other conditions were the same as entry 4.

${ }^{\mathrm{d}}[\mathrm{BMIm}] \mathrm{Cl}$ was replaced by 1-butyl-2,3-dimethyl-imidazolium chloride, other conditions were the same as entry 4 . 


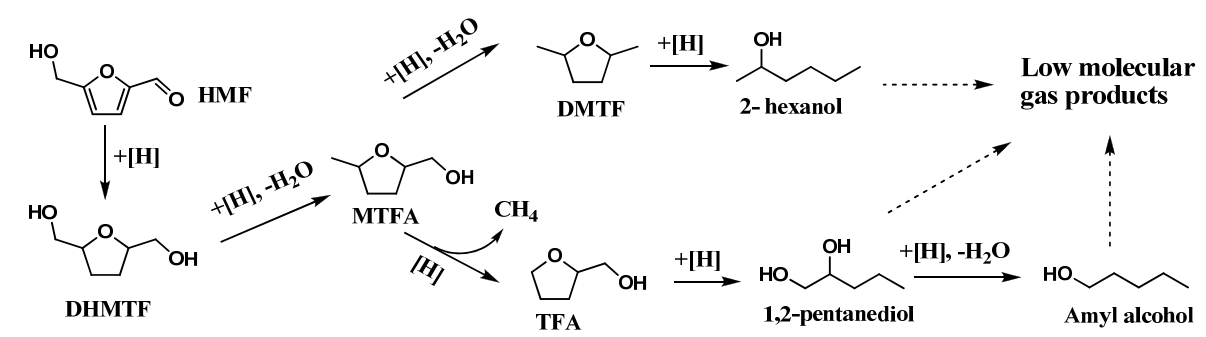

Fig. 3. Byproducts formation pathways for the hydrotreating of $\mathrm{HMF}$ with $5 \% \mathrm{Ru} / \mathrm{C}$ in $\mathrm{THF}$ without the addition of [BMIm]Cl.

in its furan ring and carbonyl group to generate DHMTF, which was convert to MTFA via hydrodeoxygenation reaction; subsequently, further hydrodeoxygenation and ring-opening reactions occurred on MTFA to afford DMTF and 2-hexanol; alternatively, MTFA was converted to TFA, 1,2-pentanediol and amyl alcohol via demethylation, ring-opening reaction and hydrodeoxygenation, respectively. Some of the above products were further cracked to gases, i.e. $\mathrm{CO}_{2}, \mathrm{CH}_{4}$ and $\mathrm{C}_{2} \mathrm{H}_{6}$, etc. As DMF was not detected in the reaction, it is suggested that the furan ring in $\mathrm{HMF}$ was very active in THF over $\mathrm{Ru} / \mathrm{C}$.

In a parallel trial with $0.2 \mathrm{~g}$ [BMIm] Cl, a DMF yield of $32 \%$ was attained (Table 2, entry 2). Clearly, the hydrogenation of the $\mathrm{C}=\mathrm{C}$ bonds in the furan ring was significantly inhibited. Further increasing the IL amount to 0.5 and $1.0 \mathrm{~g}$ slightly increased the yield of DMF to $41 \%$ and $47 \%$, and the yield of DMTF to $12 \%$ and $20 \%$, respectively (Table 2, entries 3 and 4 ). The highest total yield of $67 \%$ was obtained with $1.0 \mathrm{~g}$ [BMIm]Cl. More IL did not further increase the yields of the target products (entry 5). We assume here that the presence of the IL should have modified the catalyst, and changed the reaction route to form DMF and DMTF. This hypothesis will be further discussed later with the element analysis, Raman spectroscopy, XPS and $\mathrm{H}_{2}$-TPR characterization, together with a series of comparison experiments.

To confirm our hypothesis, the following experiment was designed. First, fresh $\mathrm{Ru} / \mathrm{C}$ was treated in IL at $220^{\circ} \mathrm{C}$ under 5 $\mathrm{MPa} \mathrm{H}_{2}$ for $2 \mathrm{~h}$. This treated catalyst was then carefully washed with water to ensure the removal of all the physically adsorbed IL, and was dried under vacuum to obtain IL-treated $\mathrm{Ru} / \mathrm{C}$ (denoted as $\mathrm{Ru} / \mathrm{C}$-IL) [28]. Using this catalyst, we performed HMF hydrodeoxygenation in pure THF under the same conditions as Table 2, entry 1 . It was interesting to find that the yield of DMF and total yield reached $66 \%$ and $67 \%$, respectively (Table 2, entry 6). Because there was no difference in the reaction conditions of the two experiments (Table 2, entries 1 and 6 ), this result suggested that there was a modification of $\mathrm{Ru} / \mathrm{C}$ during the treatment of the catalyst in IL, which hence changed its catalytic activity.

The elemental analysis of $\mathrm{Ru} / \mathrm{C}$ and $\mathrm{Ru} / \mathrm{C}$-IL supplied additional evidence of this. As the active carbon support was treated with $\mathrm{HNO}_{3}$ before use, a N content of $0.92 \mathrm{wt} \%$ was detected in fresh $\mathrm{Ru} / \mathrm{C}$. However, $\mathrm{Ru} / \mathrm{C}$-IL comprised a much higher $\mathrm{N}$ content of $4.07 \mathrm{wt} \%$. Since the IL contains $16 \mathrm{wt} \%$ of $\mathrm{N}$ and the physically adsorbed IL had been removed from $\mathrm{Ru} / \mathrm{C}$ by water washing, the increased $\mathrm{N}$ content in $\mathrm{Ru} / \mathrm{C}$-IL should be attributed to a chemical interaction between $\mathrm{Ru} / \mathrm{C}$ and the IL, which anchored the IL on $\mathrm{Ru} / \mathrm{C}$.

As the IL is composed of 1-butyl-3-methylimidazolium cation ([BMIm] $]^{+}$) and $\mathrm{Cl}^{-}$anion, to clarify the function of $\mathrm{Cl}^{-}$on the catalyst activity, the IL was replaced by an equal molar amount of $\mathrm{NaCl}$ for the HMF hydrodeoxygenation reaction under the same condition as Table 2, entry 4. It was found that although the conversion was still very high, the reaction only afforded $2 \%$ total yield of DMF and DMTF (Table 2, entry 7). This result is similar to that obtained in THF without the IL (Table 2, entry 1), suggesting that $\mathrm{NaCl}$ has no influence on the yield of the target products. Taken together, entries 1, 4 and 7 in Table 2 indicated that the $\mathrm{Cl}^{-}$did not help convert $\mathrm{HMF}$ to DMF and DMTF. Therefore, it was [BMIm] $]^{+}$that played a role in the modification of $\mathrm{Ru} / \mathrm{C}$ and its catalytic property.

$\mathrm{Ru} / \mathrm{C}$ is a typical heterogeneous catalyst comprising Ru species and a carbon support. With the aim to identify which component interacted with [BMIm] ${ }^{+}$, Raman spectroscopy, a powerful tool for carbon characterization, was performed on fresh $\mathrm{Ru} / \mathrm{C}$ and $\mathrm{Ru} / \mathrm{C}$-IL. As shown in Fig. 4, both catalysts have two strong bands at 1401 and $1519 \mathrm{~cm}^{-1}$, which were assigned to the $D$ and $G$ bands of the active carbon, respectively. No shift was detected for the two bands of $\mathrm{Ru} / \mathrm{C}$-IL as compared to those of fresh $\mathrm{Ru} / \mathrm{C}$, and the value of $I_{\mathrm{D}} / I_{\mathrm{G}}$ for both catalysts was 0.87. These facts indicated that the structure of the carbon support was not changed after the treatment of the catalyst in the IL. Thus, the high yield of the furan-based fuels can be ascribed to the interaction of [BMIm] ${ }^{+}$with the metal species.

Kiefer and co-workers [29] have shown that $\mathrm{H}$ atom on the $\mathrm{C}_{2}$ position of the positively charged ring in 1,3-dialkylimidazolium-based IL is very active. It is easy to eliminate, leaving a $\mathrm{N}$-heterocyclic carbene structure on the imidazolium ring. The

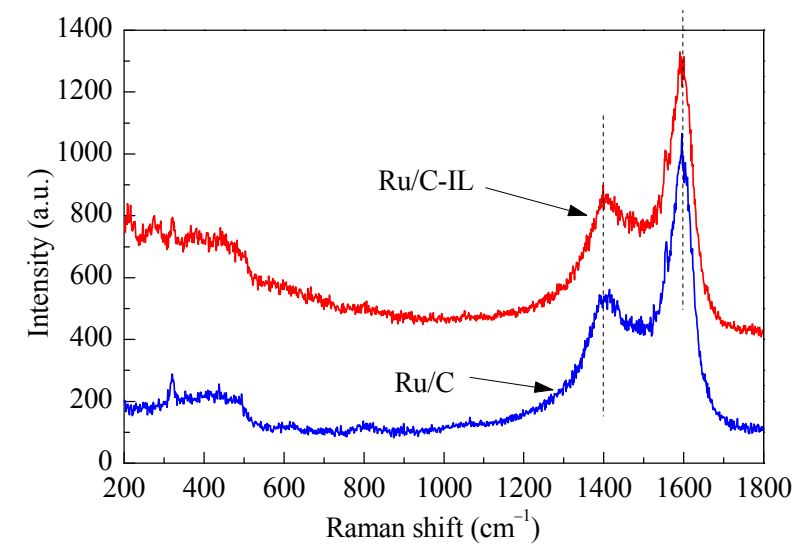

Fig. 4. Raman spectra of fresh $\mathrm{Ru} / \mathrm{C}$ and $\mathrm{Ru} / \mathrm{C}-\mathrm{IL}$. 
presence of the carbene structure was suggested to have a remarkable effect on metal-catalyzed reactions through coordination $[30,31]$. To identify whether this "carbene effect" was present in our catalytic system, 1-butyl-2,3-dimethylimidazolium chloride ([BDMIm]Cl) was prepared for the HMF hydrodeoxygenation reaction. Unlike [BMIm]Cl, [BDMIm]Cl cannot form a carbene structure since the $\mathrm{C}_{2}$ site of the imidazolium ring is occupied by a methyl group. The result showed that under the same conditions, both the ILs gave similar performances (entry 4 versus entry 8 , Table 2). This indicated that methylating the $\mathrm{C}_{2}$ position did not affect the catalytic activity of the $\mathrm{Ru}$ species. Therefore, $\mathrm{H}$ atom on the $\mathrm{C}_{2}$ position of the imidazolium ring is not the reason for the high yield of furan-based fuels.

The ligand effect is the use of a ligand to alter the electronic properties of the active metal by electron transfer from the ligand to the metal species [32]. This "ligand (or electronic) effect" significantly affects the catalytic activity and selectivity in various chemical reactions [33]. An obvious feature of the 1,3-dialkylimidazolium cation is that one of the $\mathrm{N}$ atoms in the imidazolium ring contains a lone pair electron [34]. This $\mathrm{N}$ atom can act as a ligand to coordinate with the $\mathrm{Ru}$ species and thus modify the electronic property of the actives site. XPS characterization of the catalyst demonstrated the "ligand effect" of the IL on the Ru species. In the XPS measurement, since the $\mathrm{Ru} 3 d_{5 / 2}$ peak overlapped with that of $\mathrm{C} 1 s$ [35], the binding energy of the $\mathrm{Ru} 3 p_{3 / 2}$ orbital was measured. As shown in Fig. $5(\mathrm{a})$, the binding energy of $\mathrm{Ru} / \mathrm{C}$-IL was $0.4 \mathrm{eV}$ lower than that of fresh $\mathrm{Ru} / \mathrm{C}(463.5 \mathrm{eV})$, indicating that the electron cloud density of the Ru species was increased after treating with the IL. Due to the conjugative effect of the imidazolium ring, the $\mathrm{N}$ $1 s$ of [BMIm]Cl in C-IL (IL treated carbon) [28] only exhibited one peak (401.6 eV, Fig. 5(b)). However, it was interesting to find that two N $1 s$ peaks of 399.8 and $401.2 \mathrm{eV}$ appeared in the $\mathrm{Ru} / \mathrm{C}$-IL sample (Fig. 5(b)), suggesting that one $\mathrm{N}$ atom was coordinated with the $\mathrm{Ru}$ species, resulting in the different binding energy for the two $\mathrm{N}$ atoms in the imidazolium ring of [BMIM]Cl.

$\mathrm{H}_{2}$-TPR measurement further confirmed the modification of

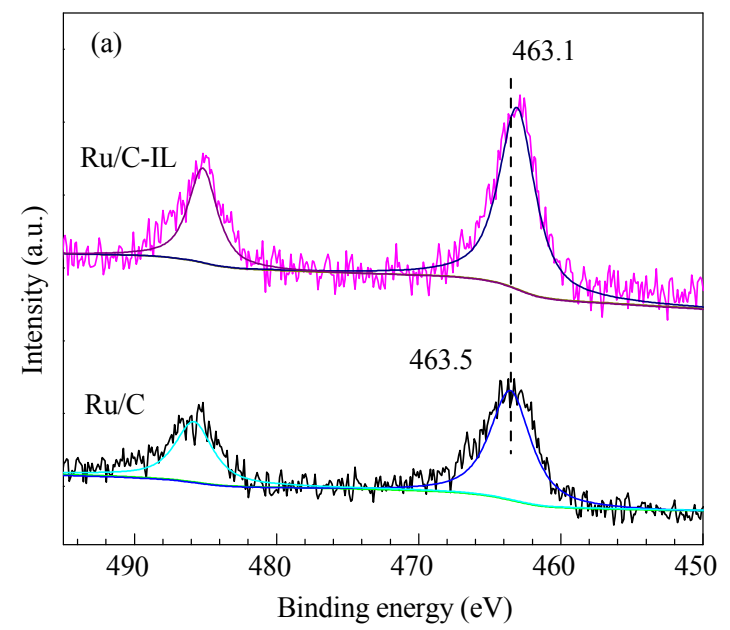

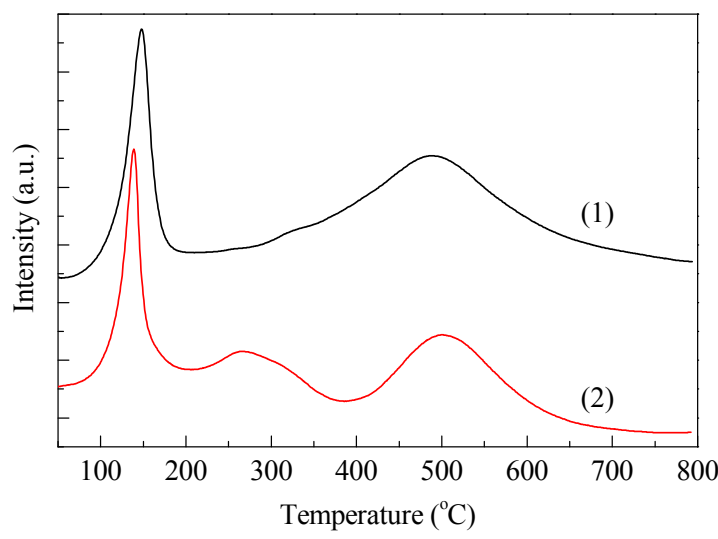

Fig. 6. $\mathrm{H}_{2}$-TPR profiles of $\mathrm{Ru} / \mathrm{C}(1)$ and $\mathrm{Ru} / \mathrm{C}-\mathrm{IL}(2)$.

the Ru electron properties. Fig. 6 summarizes the TPR profiles of fresh $\mathrm{Ru} / \mathrm{C}$ and $\mathrm{Ru} / \mathrm{C}$-IL. In the low temperature region of $140{ }^{\circ} \mathrm{C}$, only one peak was detected for both catalysts, which was ascribed to the reduction of $\mathrm{RuO}_{2}$. The hydrogen consumption signals at $270{ }^{\circ} \mathrm{C}$ and $510{ }^{\circ} \mathrm{C}$ were accompanied by the formation of methane (confirmed by MS analysis), suggesting that some carbon species were reduced to methane. In the TPR profile of $\mathrm{Ru} / \mathrm{C}$-IL, it is interesting that the peak at $270{ }^{\circ} \mathrm{C}$ was much larger than that of $\mathrm{Ru} / \mathrm{C}$. Obviously, after treating with the IL, the $\mathrm{Ru}$ species was greatly changed in property, which probably led to some methanation of the support. These changes to the Ru species are believed to be responsible for the much improved hydrodeoxygenation performance.

\section{Conclusions}

We achieved the direct production of furan-based fuels, DMF and DMTF, from fructose via one-pot tandem reactions. The nature of the organic solvent in the IL containing binary solvent mixture and the water amount strongly affected the reaction. Characterization of the catalysts and the parallel experiments indicated that the interaction between the cations of the IL and Ru species changed the charge density of the metal

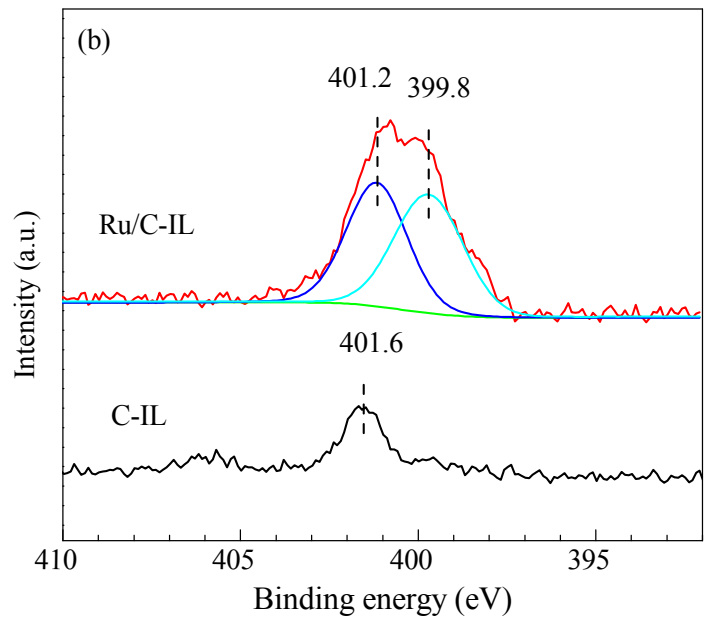

Fig. 5. XPS spectra of Ru/C, Ru/C-IL and C-IL. (a) Ru 3pp/2; (b) N $1 s$. 
species, which is the reason for the high selectivity of the furan-based fuels. The advantages of the IL in the fructose dehydration reaction, its role in the modification of the $\mathrm{Ru}$ species, as well as the biphasic [BMIm]Cl/THF solvent system together gave the high yield of furan-based fuels. This catalytic system featured a simple process with no need for intermediate separation processes and it gave a high performance, which brings this technology nearer to the cost-efficient production of biofuels from biomass.

\section{References}

[1] Wang A Q, Zhang T. Acc Chem Res, 2013, 46:1377

[2] Zheng M Y, Pang J F, Wang A Q, Zhang T. Chin J Catal (郑明远, 庞纪 峰, 王爱琴, 张涛. 催化学报), 2014, 35: 602

[3] Tuck C 0, Perez E, Horvath I T, Sheldon R A, Poliakoff M. Science, 2012, 337: 695

[4] Besson M, Gallezot P, Pinel C. Chem Rev, 2014, 114: 1827

[5] Roman-Leshkov Y, Barrett C J, Liu Z Y, Dumesic J A. Nature, 2007, 447: 982

[6] Do P T M, McAtee J R, Watson D A, Lobo R F. ACS Catal, 2013, 3: 41

[7] Shiramizu M, Toste F D. Chem Eur J, 2011, 17: 12452

[8] Stahlberg T, Fu W J, Woodley J M, Riisager A. ChemSusChem, 2011, 4: 451

[9] Hansen T S, Barta K, Anastas P T, Ford P C, Riisager A. Green Chem, 2012, 14: 2457

[10] Zu Y H, Yang P P, Wang J J, Liu X H, Ren J W, Lu G Z, Wang Y Q. Appl Catal, B, 2014, 146: 244

[11] Chidambaram M, Bell A T. Green Chem, 2010, 12: 1253

[12] Binder J B, Raines R T. J Am Chem Soc, 2009, 131: 1979

[13] Thananatthanachon T, Rauchfuss T B. Angew Chem Int Ed, 2010, 49: 6616

[14] Yang W R, Sen A. ChemSusChem, 2010, 3: 597

[15] Wang H, Gurau G, Rogers R D. Chem Soc Rev, 2012, 41: 1519

[16] Tadesse H, Luque R. Energy Environ Sci, 2011, 4: 3913

[17] Yi Y X, Shen Y, Sun J K, Wang B, Xu F, Sun R C. Chin J Catal (易宇轩, 申越, 孙建奎, 王波, 徐风, 孙润仓. 催化学报), 2014, 35: 757
[18] Cai H L, Li C Z, Wang A Q, Xu G L, Zhang T. Appl Catal, B, 2012, 123: 333

[19] Li C Z, Zhao Z K, Cai H L, Wang A Q, Zhang T. Biomass Bioenerg, 2011, 35: 2013

[20] Cai H L, Li C Z, Wang A Q, Zhang T. Catal Today, 2014, 234: 59

[21] van Putten R J, van der Waal J C, de Jong E, Rasrendra C B, Heeres H J, de Vries J G. Chem Rev, 2013, 113: 1499

[22] Fendt S, Padmanabhan S, Blanch H W, Prausnitz J M. J Chem Eng Data, 2011, 56: 31

[23] Reichardt C, Welton T. Solvents and Solvent Effects in Organic Chemistry. 4th Ed. New York: Wiley-VCH, 2011. 303

[24] Ficke L E, Brennecke J F. J Phys Chem B, 2010, 114: 10496

[25] Zhao Y L, Liu X M, Wang J J, Zhang S J. J Phys Chem B, 2013, 117: 9042

[26] Roman-Leshkov Y, Chheda J N, Dumesic J A. Science, 2006, 312: 1933

[27] Dong K, Zhang S J. Chem-Eur J, 2012, 18: 2748

[28] Detail experimental process for the pretreatment of $\mathrm{Ru} / \mathrm{C}$ in [BMIm] Cl is as follows: $200 \mathrm{mg}$ catalyst was added in $2.0 \mathrm{~g}$ [BMIm] $\mathrm{Cl}$ and stirred at $220^{\circ} \mathrm{C}$ under $5 \mathrm{MPa} \mathrm{H}_{2}$ for $2 \mathrm{~h}$. Then the reaction mixture was diluted with $10 \mathrm{ml}$ cold deionized water, the precipitated $\mathrm{Ru} / \mathrm{C}$ was filtered, and washed additional five times to ensure the removal of all the free [BMIm]Cl. The attained IL-treated $\mathrm{Ru} / \mathrm{C}$ was finally dried under vacuum to obtain $\mathrm{Ru} / \mathrm{C}$-IL. For the treatment of carbon with IL, the process is similar to that of $\mathrm{Ru} / \mathrm{C}-\mathrm{IL}$.

[29] Noack K, Schulz P S, Paape N, Kiefer J, Wasserscheid P, Leipertz A. Phys Chem Chem Phys, 2010, 12: 14153

[30] Praetorius J M, Crudden C M. Dalton Trans, 2008, (31): 4079

[31] Lebel H, Janes M K, Charette A B, Nolan S P. J Am Chem Soc, 2004, 126: 5046

[32] Alonso D M, Wettstein S G, Dumesic J A. Chem Soc Rev, 2012, 41: 8075

[33] Yoon B, Haekkinen H, Landman U, Woerz A S, Antonietti J M, Abbet S, Judai K, Heiz U. Science, 2005, 307: 403

[34] You H X, Wang Y Y, Wang X Z. Progr Chem (尤洪星, 王永勇, 王雪 珠, 刘晔. 化学进展), 2013, 25: 1656

[35] Ren J W, Ding J, Chan K Y, Wang H T. Chem Mater, 2007, 19: 2786

\section{Graphical Abstract}

Chin. J. Catal., 2015, 36: 1638-1646 doi: 10.1016/S1872-2067(15)60927-5

\section{Tailored one-pot production of furan-based fuels from fructose in an ionic liquid biphasic solvent system}

Changzhi Li, Haile Cai, Bo Zhang, Weizhen Li, Guangxian Pei, Tao Dai, Aiqin Wang, Tao Zhang *

Dalian Institute of Chemical Physics, Chinese Academy of Sciences; University of Chinese Academy of Sciences; Collaborative Innovation Center of Chemistry for Energy Materials (iChEM)

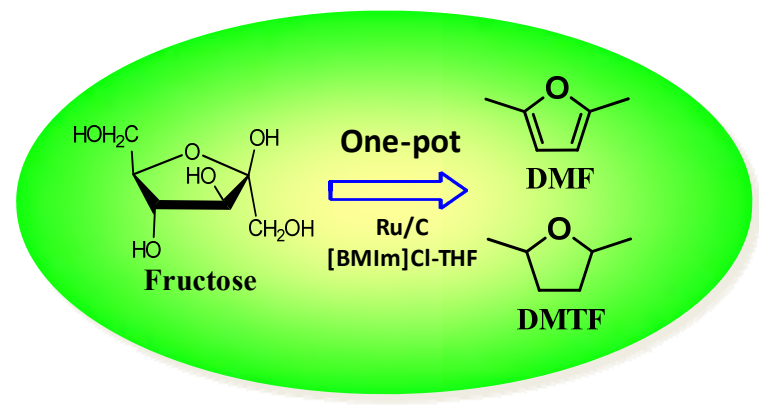

One-pot production of 2, 5-dimethylfuran and 2, 5-dihmethyltetrahydrofuran from fructose by optimizing the synergic effect of ionic liquid promoted $\mathrm{Ru} / \mathrm{C}$ catalyst and solvent effect was reported. 


\title{
果糖一步转化制备呋喃基燃料: 溶剂效应及离子液体修饰活性金属对 产物选择性的决定作用
}

\author{
李昌志 ${ }^{\mathrm{a}}$, 蔡海乐 ${ }^{\mathrm{a}}$, 张 波 ${ }^{\mathrm{a}}$, 李为臻 ${ }^{\mathrm{a}}$, 裴广贤 ${ }^{\mathrm{a}, \mathrm{b}}$, 代 㢷 ${ }^{\mathrm{a}, \mathrm{b}}$, 王爱琴 ${ }^{\mathrm{a}, \mathrm{c}}$, 张 涛, ${ }^{\mathrm{a}, \text {, }}$ \\ ${ }^{\mathrm{a}}$ 中国科学院大连化学物理研究所催化基础国家重点实验室, 辽宁大连 116023 \\ ${ }^{\mathrm{b}}$ 中国科学院大学, 北京100049 \\ $\mathrm{c}$ 能源材料化学协同创新中心, 辽宁大连 116023
}

摘要: 在众多生物基化合物中, 2,5-二甲基呋喃(DMF)是一种有实用前景的可再生液体生物质燃料, 也是一种具有重要价值的化 学品, 可作为生产对苯二甲酸的原料. 2,5-二甲基四氢呋喃(DMTF)是DMF进一步加氢产物, 该化合物比DMF更稳定, 适合长期保 存; 由于具有更高的氢碳比, 用作生物燃料燃烧时能够释放更多能量. 研究生物质资源制备DMF和DMTF对可再生资源制备液体 燃料和化学品具有重要意义. 从生物质多糖出发制备这两类化合物, 中间经历了水解、脱水、加氢、加氢脱氧等多个反应步骤, 每 一步反应都十分复杂, 包含许多副反应途径. 此外, 由于每一步反应条件的不兼容性, 大多数研究集中在分步反应阶段, 鲜有文献 能够实现从碳水化合物原料直接转化为DMF和DMTF. 发展由生物质一锅法多步耦合转化技术制备化学品和燃料, 不仅具有科 学意义, 而且可大大简化反应过程, 避免中间产物分离和损失, 节省资源和时间, 历来受到化学家和工业界的关注.

本文利用离子液体对 $\mathrm{Ru} / \mathrm{C}$ 催化剂电子性质的修饰作用以及溶剂效应的影响, 设计了离子液体/THF双相体系中果糖直接催化 转化制备2,5-二甲基呋喃(DMF)和2,5-二甲基四氢呋喃(DMTF)的新路线. 该转化过程耦合了果糖脱水制HMF、HMF加氢及加氢脱 氧生成DMF和DMTF等多步反应. 通常在HMF加氢转化过程中, Ru/C催化剂的高活性易导致HMF深度加氢生成大量开环产物及 气体, 我们借助离子液体与有机溶剂的不同溶解性, 篮选出 [BMIm]Cl/THF双相溶剂体系, 使极性HMF在离子液体层反应, 生成弱 极性的DMF和DMTF能及时被THF萃取出来, 有效稳定了目标产物. 其次, 果糖转化为HMF会产生少量水, 通常水的存在易导致 $\mathrm{HMF}$ 发生水合等副反应, 对下一步的加氢转化是不利因素; 然而在本催化体系中, 由于 [BMIm]Cl能与水以较强的氢键结合形成 水合物, 对水分子起到了束缚作用, 减少了HMF发生水解、水合等副反应的机会. 另一方面, 离子液体粘度较大, 微量水的存在能 降低离子液体层粘度, 改善传质, 从而提高反应速率.

在HMF加氢处理过程中, 离子液体对DMF和DMTF的生成起了决定作用. 当反应体系中不添加离子液体, 以 THF为溶剂, 反 应结束后未检测到DMF生成, DMTF的收率仅为 $2 \%$, 但HMF 已经完全转化. 取气体样品进行 GC分析, 发现有部分气相产物生成, 包括 $\mathrm{CO}_{2} 、 \mathrm{CH}_{4}$ 和 $\mathrm{C}_{2} \mathrm{H}_{6}$ 等. 液体混合物进行 GC-MS检测, 发现产物主要包括DHMTF、5-甲基四氢糠醇(MTFA)、四氢糠醇(TFA)、 1,2-戊二醇、DMTF、2-己醇和少量戊醇, 产物中所有呋喃环结构的双键都发生加氢反应. 以上结果表明, 没有离子液体的THF中, $\mathrm{Ru} / \mathrm{C}$ 催化的 $\mathrm{HMF}$ 涉氢反应平衡已发生改变. 当反应体系中添加 $0.2 \mathrm{~g}$ 离子液体 $[\mathrm{BMIm}] \mathrm{Cl}$ 进行 HMF的加氢时, 此时开始有DMF生 成, 随着 $[\mathrm{BMIm}] \mathrm{Cl}$ 量依次增加, DMF以及DMTF的收率也呈上升趋势. $1.0 \mathrm{~g}$ 离子液体获得两种产物最高收率为 $68 \%$. 然而, 如果进 一步增加 [BMIm] $\mathrm{Cl}$ 的量到 $2.0 \mathrm{~g}$, 呋喃基液体燃料DMF和DMTF的收率却开始下降. 综合以上实验结果, 我们认为适量的 $[\mathrm{BMIm}] \mathrm{Cl}$ 存在有可能会对催化剂物理化学性质造成影响, 从而对产物的选择性起了决定性作用. 通过对催化剂进行元素分析、 XPS、 $\mathrm{H}_{2}$-TPR 表征以及一系列对比实验证明, 离子液体不仅促进果糖脱水转化为HMF, 同时在HMF选择性加氢反应中可修饰活性 金属电子性质, 改变催化路径, 是多步串联反应能够耦合的关键因素.

在 $[\mathrm{BMIm}] \mathrm{Cl} / \mathrm{THF}$ 双相溶剂体系中, 离子液体的 “溶剂笼效应” 促进DMF和DMTF高效生成, THF的萃取功能对目标产物的稳 定起了关键作用. 以上对催化剂和溶剂的合理设计共同促进高产率呋喃基燃料的获得. 该研究实现由六碳糖直接选择转化获取 DMF和DMTF, 为生物质高效催化转化制备生物基能源化学品提供了新思路.

关键词: 生物质; 离子液体; 2,5-二甲基呋喃; 2,5-二甲基四氢呋喃; 5-羟甲基糠醛; 果糖; 生物燃料

收稿日期: 2015-03-29. 接受日期: 2015-06-03. 出版日期: 2015-09-20.

*通讯联系人. 电话: (0411)84379015; 传真: ((0411)84691570; 电子信箱: taozhang@dicp.ac.cn

基金来源：国家自然科学基金(21473187, 21403213); 中国博士后科学基金(2015M571341).

本文的英文电子版由Elsevier出版社在ScienceDirect上出版(http://www.sciencedirect.com/science/journal/18722067). 